\title{
EFFECT OF GENDER ON FAST-FOOD CONSUMPTION HABITS OF HIGH SCHOOL AND UNIVERSITY STUDENTS IN TEKIRDAG, TURKEY
}

\author{
S. KAYISOĞLU* and A. İçöZ \\ Department of Food Technology, Vocational School of Technical Sciences, Namık Kemal University, \\ 59030 Tekirdağ. Turkey
}

(Received: 2 June 2012, accepted: 6 August 2012)

\begin{abstract}
In this research, the effect of gender on fast-food consumption has been studied to determine fast-food consumption habits with a survey given to 900 people including Tekirdag city centre high school students and Namik Kemal University students. Also, the relationship between fast-food consumption and overweight, and whether the students have trust for hygiene applications of fast food producing and service enterprises has been studied. 900 people in total were involved in this research (459 females and 441 males). According to the results of the survey, a significant relationship between gender and fast-food choice type, portion size, consumption frequency, trust for complying hygiene rules, the need of being informed about food security, being affected by commercials, food poisoning and the reaction to it, and not consuming fast-food has been found.

Many Turkish adolescents are becoming increasingly more westernized and have greater convenience when they eat out. Fast-food type nutrition which is popular among children and teenagers contains deficient or excess nutrients. High schools and universities are appropriate establishments for students to gain correct nutritional habits. This research has been planned to determine fast-food preferences of different gender.
\end{abstract}

Keywords: fast food consumption, food security, fast food eating habits

For humans, to maintain a healthy and strong life depends on a diet that is well balanced. This is especially true for those in the growing age (DEMIRCI, 2002). A 2001 survey of 4746 children and teenagers, 11 to 18 years old, showed that fast-food consumption was associated with higher intakes of cheeseburgers, French fries, pizzas, and soft drinks, and lower intakes of fruits, vegetables, and milk (FrENCH et al., 2001). The developments in the nutrition industry and technologies have had a great contribution to the quick development of the fastfood nutrition system (GüLER \& ÖZÇELIK, 2002). Fast foods have been defined by BENDER and BENDER (1995) as a "general term used for a limited menu of foods that lend themselves to production-line techniques; suppliers tend to specialize in products, such as hamburgers, pizzas, chicken, or sandwiches" (DAvies \& SMITH, 2004). The fast food restaurant is one typical form of global business (EMERSON, 1990; PARK, 2004). Fast-food restaurants are those in which one can order, purchase, and receive the food in about $10 \mathrm{~min}$ (SPEARs \& GREGOIRE, 2003); this includes traditional fast-food restaurants where customers order and receive food at counters and drive-in locations as well as fast/casual restaurants where customers order at counters and their food is delivered to the table. The frequency of fast-food consumption has dramatically increased since the early 1970s (French et al., 2000; PAERATAKUL et al., 2003). The Turkish fast food industry has grown rapidly since the 1980s. There are now more than 700 fast food restaurants in Turkey. The major changes in the lifestyle, education, income, and consumption patterns of Turkish consumers in the last two decades encouraged consumers

\footnotetext{
* To whom correspondence should be addressed.

Phone: +90 282 2504000; fax: +90 282 2509934; e-mail: skayisoglu@nku.edu.tr
} 
to eat out. Although the fast food is not cheap, many young Turkish people consider fast food restaurants as social and proper places of meeting and eating out (AKBAY et al., 2007). The growing number of fast food chains and restaurants in newly established shopping centres and hypermarket complexes are evidence of this newly emerging demand. Many Turkish adolescents are becoming increasingly westernized and have greater convenience when they eat out. On the other hand, the preference of the older generation is different than of the younger generation in Turkey. However, fast food has still represented a small percentage (less than 10\%) in total food expenditures in Turkey in 2003 (SIS, 2003). College students frequently consume fast foods (NickOlas et al., 2001; Driskell et al., 2005). Eating at fastfood restaurants appears to be part of the lifestyles of college students (DRISKELL et al., 2005). Fast-food type nutrition which is regarded popular among children and teenagers contains deficient or excess nutrients. This situation causes diseases, such as obesity, diabetes, heart disease, angiopathy, and cancer (SAĞLAM, 1991). Nutrition experts attract attention to the possibility of large intestine cancer risk when we consume fast food. Obesity has also been associated with fast-food consumption (SATIA et al., 2004). Food safety is a growing concern for consumers and professionals in the food and foodservice sectors (SCHEULE \& SNEED, 2001). It has been defined as the conditions and measures that are necessary during production, processing, storage, distribution and preparation of food to ensure that it is safe, sound, wholesome, and fit for human consumption (WHO, 1984).

This research has been planned to determine fast-food preferences of different gender.

\section{Materials and methods}

This survey has been made with 568 students from Namik Kemal University and 332 students from high schools located in the city centre of Tekirdağ to study the effect of gender on fastfood consumption habits. The results obtained were evaluated by the test of Chi-square. The questionnaire was pilot tested on 10 comparable consumers for clarity and validity; adjustments were made where necessary (BADRIE et al., 2004). Respondents provided selfreported anthropometric measurements. Body mass indices (BMIs) were calculated as the weight in kilograms divided by the square of height in meters (GARROw \& WEBSTER, 1985). According to this index, the subjects were categorized as follows: $\mathrm{BMI}<18.5$ are underweight, $18.5<\mathrm{BMI}<24.9$ normal, $25.0<\mathrm{BMI}<29.9$ are overweight, and $\mathrm{BMI}>30.0$ are obese (LuTZ \& PRZYTULSKI, 2001).

Research data were analysed by using the SPSS statistical package program. Chi-square $\left(\gamma^{2}\right)$ importance test was used for statistical analysis.

\section{Results and discussion}

Fifty-one percent of the respondents are women and $49 \%$ are men, age distribution is $14-15$ (11.2\%), 16-17 (22.8\%), 18-19 (18.3\%), 20-21 (34.3\%), and 22 and over (13.3\%); 36.9\% of the respondents are high school students, $5.8 \%$ are from university, $29.6 \%$ are from vocational high school, and $27.8 \%$ of the respondents are faculty students. When the respondents are evaluated according to the BMI index it was found that $16.3 \%$ are underweight, $71.2 \%$ are normal, $10.8 \%$ are overweight, and $1.7 \%$ are obese. 
It is found that the effect of gender on the BMI index is significant $\left(\gamma^{2}=56.17 ; \mathrm{P}<0.01\right)$ (Table 1). According to the research conducted by ÖzçELIK and co-workers (2007), the percentage of females with a normal body weight was higher than for males, while the percentage of the overweight and obese males was higher than that of the females. In Canada, obesity prevalence has risen significantly since the 1970s, and with it the risk of developing cardiovascular diseases, diabetes, physical disabilities, and other undesired health conditions (KATZMARZYK, 2002). From 1978 to 2004 measured age-adjusted obesity rates for adults increased from $14 \%$ to $23 \%$ (STATISTICS CANADA, 2006) and childhood obesity has tripled over the last 25 years. As of 2004, 26\% of Canadian children and adolescents aged 2-17 years were overweight or obese (SHIELDS, 2006). According to our results, the percentage of overweight and obese people is lower in Turkey.

Table 1. BMI of respondents

\begin{tabular}{lcc}
\hline BMI & Female (\%) & Male (\%) \\
\hline Underweight & 23.7 & 8.9 \\
Normal & 69.3 & 73.2 \\
Overweight & 6.5 & 15.2 \\
Obese & 4.0 & 2.9 \\
\hline
\end{tabular}

Instead of home cooked meal, $34.6 \%$ of the female respondents choose fast food. This rate is $39.2 \%$ among male respondents. The effect of gender over fast food choice is trivial $\left(\gamma^{2}=2.03 ; \mathrm{P}>0.05\right)$. Among the women $10.5 \%$ and $17.7 \%$ of the men said that fast-food does not negatively affect nutrition culture. In this regard the effect of gender is significant $\left(\gamma^{2}=19.03 ; \mathrm{P}<0.01\right)$.

Among the women $37.9 \%$ mentioned that they chose fast food because it is delicious, while $42.2 \%$ of the men said that they chose it because it is prepared quickly. The effect of gender on fast food choice reasons is not significant $\left(\gamma^{2}=13.70 ; \mathrm{P}>0.05\right)$. ÖzGEN and SANLIER (2002) discovered in their study conducted on students of 17 to 24 years that the first reason for fast-food preference was its taste and the second reason was that it is served fast. DEMORYLuCE (2005) determined that the tendency of consuming fast-food has increased due to its fast service, appropriateness, taste, and reasonable prices. According to research carried out by Meyers and WALlace (2003), it was determined that the main factors for the preferences of costumers were cleanliness, taste, and employee competence. According to a study conducted in Singapure, among the factors that affect the fast-food restaurant preferences of the participants, the first three were convenience (26.4\%), speed of service (18.6\%), and price (13.1\%) (ANon., 2004). According to Morse and Driskell (2009) a significantly larger percentage of college men than women in the current study indicated eating fast foods because they perceived fast foods as being "inexpensive and economical". The top 4 reasons given by the students in the present study for consuming fast foods (they could select as many reasons as applied) were "limited time," "enjoy the taste," "eat with friends/family," and "inexpensive and economical." DRISKELL and co-workers (2005) determined that the top 3 reasons given were in agreement with those of a 2004 study at their university.

Most of the respondents chose hamburger (31.3\%) and pizza $(22.1 \%)$ as fast food (Table 2). A significant relationship between gender and fast food choice has been found $\left(\gamma^{2}=87.34 ; \mathrm{P}<0.01\right)$. According to the research conducted by ÖzçELIK and co-workers (2007), 
the average preference points of the females who preferred hamburger, pizza, chicken and sandwich restaurants are higher than the average points of the males; whereas, the average points of preference for 'pide', 'lahmacun', and kebab and 'köfte' restaurants are higher for males. It has been determined that the average preference points for hamburger $(\mathrm{P}<0.05)$, pizza $(\mathrm{P}<0.05)$, 'lahmacun' $(\mathrm{P}<0.05)$, sandwich $(\mathrm{P}<0.01)$, and kebab and 'köfte' $(\mathrm{P}<0.01)$ restaurants as per gender show significant difference.

Table 2. Percentages of male and female students who reported eating fast food

\begin{tabular}{lcc}
\hline Eatables & Female (\%) & Male (\%) \\
\hline Hamburger & 38.8 & 23.6 \\
Pizza & 28.5 & 15.4 \\
Döner & 10.5 & 22.7 \\
Lahmacun & 9.2 & 9.8 \\
Sandviç & 1.5 & 2.3 \\
Pide & 2.4 & 2.7 \\
Kebap-Köfte & 7.6 & 15.9 \\
Kokoreç & 1.5 & 7.7 \\
\hline
\end{tabular}

The relationship between gender and hamburger type is significant $\left(\gamma^{2}=32.26 ; \mathrm{P}<0.01\right)$, as shown in Table 3.

Table 3. The relationship between gender and hamburger type

\begin{tabular}{lcc}
\hline $\begin{array}{l}\text { Hamburger } \\
\text { type }\end{array}$ & Female (\%) & Male (\%) \\
\hline Chicken burger & 58.4 & 39.5 \\
Meat burger & 41.6 & 60.5 \\
\hline
\end{tabular}

Among the women $92.6 \%$ and $87.8 \%$ of the men chose going to the fast food restaurants with friends. The effect of gender over the choice about with whom to go to fast food restaurant is significant $\left(\gamma^{2}=16.16 ; \mathrm{P}<0.01\right)$.

Most of the respondents $(87.7 \%)$ said that they were not influenced by the brand. In fast food choice the relationship between brand and gender is not significant $\left(\gamma^{2}=6.54 ; \mathrm{P}>0.05\right)$.

Women choose smaller portions in comparison to men. The effect of gender on portion choice is significant $\left(\gamma^{2}=62.82 ; \mathrm{P}<0.01\right)$. According to DrISKELL and co-workers (2006), fifty percent of the men reported not typically considering portion sizes, and $53 \%$ of women reported typically considering small portion sizes when ordering.

The effect of gender on drink choice is not significant $\left(\gamma^{2}=8.38 ; \mathrm{P}>0.05\right)$ (Table 4). According to DRISKELL and co-workers (2006), a significantly larger percentage of men $(41 \%)$ than women $(21 \%)$ typically ordered carbonated soda, whereas the reverse was reported for carbonated diet soda ( $14 \%$ vs $31 \%)$.

Among the women $33.3 \%$ and $44 \%$ of the men said that they preferred fast food several times a week. The effect of gender on fast food consumption frequency is significant $\left(\gamma^{2}=23.86 ; \mathrm{P}<0.01\right)$ (Table 5). According to DrisKELL and co-workers (2006), a significantly higher percentage of men (84\%) than women (58\%) reported typically eating fast foods for lunch at least once a week. 
Table 4. The relationship between gender and drink choice

\begin{tabular}{lcc}
\hline Drink choice & Female (\%) & Male (\%) \\
\hline Nothing & 0.4 & 0.5 \\
Water & 2.0 & 2.7 \\
Coke & 60.3 & 62.8 \\
Diet drinks & 2.6 & 0.9 \\
Fruit juice & 14.4 & 10.2 \\
Ayran & 20.3 & 22.9 \\
\hline
\end{tabular}

Table 5. The effect of gender on fast food consumption frequency

\begin{tabular}{lcc}
\hline $\begin{array}{l}\text { Fast food } \\
\text { consumption frequency }\end{array}$ & Female (\%) & Male (\%) \\
\hline Daily & 9.6 & 14.7 \\
A few times a week & 33.3 & 44.0 \\
Weekly & 27.2 & 18.6 \\
Fortnightly & 16.8 & 11.6 \\
Monthly & 13.1 & 11.1 \\
\hline
\end{tabular}

Among the women $96.7 \%$ and $92.1 \%$ of the men mentioned that frequent fast food consumption is harmful for health. This is related to gender $\left(\gamma^{2}=9.34 ; \mathrm{P}<0.02\right)$. Among the women $91.1 \%$ and $81.9 \%$ of men think that fast food consumption causes weight gain. The relationship between gender and weight gain caused by fast food consumption is significant $\left(\gamma^{2}=16.38 ; \mathrm{P}<0.01\right)$.

Among the women $68.4 \%$ and $56.7 \%$ of men said that hygiene rules are not followed by fast food restaurants. The effect of gender on trust for following hygiene rules in fast food restaurants is significant $\left(\gamma^{2}=13.95 ; \mathrm{P}<0.01\right)$.

While mostly $(52.7 \%)$ noon time is preferred for fast food as a meal, it is followed by evening meal with $28.0 \%$. Meal choice is not related with gender $\left(\gamma^{2}=9.86 ; \mathrm{P}>0.05\right)$. Among the respondents $87.8 \%$ claim that nutrition additives are used during fast food preparation, while $12.2 \%$ claim that they are not used. Among the respondents $29.8 \%$ said that they have enough information, $15.8 \%$ of the respondents have no information, and $54.4 \%$ have enough information about nutrition additives.

About being informed about food safety it is mentioned that $8.1 \%$ of the women used magazines and books, other sources were: $27.5 \%$ internet, $37.9 \%$ radio and tv, $5.7 \%$ conference-seminar, and $20.9 \%$ school education; while $5.9 \%$ of the men used magazines and books, other sources were: $40.4 \%$ internet, $32.4 \%$ radio and $t v, 5.2 \%$ conference-seminar, and $16.1 \%$ school education. The effect of gender is significant on the type of food safety information $\left(\gamma^{2}=17.42 ; \mathrm{P}<0.02\right)$. According to KARABUDAK and co-workers (2008), effective public education programs targeted the microbiological, chemical, and physical sources of foodborne diseases, the essentiality of eliminating poor food hygiene practices, ensuring the safety of foods prepared at home.

In fast food choice, $60.6 \%$ of the women and $51.5 \%$ of the men said they are affected by commercials. The relationship between gender and being influenced by commercials is found significant $\left(\gamma^{2}=7.55 ; \mathrm{P}<0.04\right)$. 
The effect of gender on being poisoned by fast food consumption is significant $\left(\gamma^{2}=14.43\right.$; $\mathrm{P}<0.01$ ) (Table 6). In Turkey, 84340 and 77515 cases of foodborne disease were identified in 1999 and 2000, respectively (WHO, 2004). Because the reporting of foodborne illnesses to a specified agency is not obligatory in Turkey, data on foodborne infections and intoxications are inaccurate (WHO, 2004).

Table 6. The effect of gender on being poisoned by fast food

\begin{tabular}{lcc}
\hline & Female (\%) & Male (\%) \\
\hline Never & 91.7 & 85.0 \\
At least once & 7.6 & 11.1 \\
Several times & 0.7 & 3.9 \\
\hline
\end{tabular}

As a reaction to food poisoning, 32.9\% of the respondents complained to the firm, $20.9 \%$ complained to the health department, $18.6 \%$ complained to consumer rights association. Among the respondents $9.2 \%$ did not complain, while $18.4 \%$ said they will no longer consume fast food. Among the women $37.5 \%$ and $28.1 \%$ of the men said they will complain to the firm. The effect of gender on how to react to food poisoning is significant $\left(\gamma^{2}=23.76 ; \mathrm{P}<0.01\right)$.

As the source of fast food poisoning, $24.1 \%$ of the respondents mentioned microbial poisoning, $13.6 \%$ chemical contamination, $27.2 \%$ hygiene deficiency, $6.6 \%$ uneducated staff, and $28.6 \%$ of the respondents mentioned products passing shelf-life time.

As the reason why not to consume fast food, $37.2 \%$ of the respondents mentioned it is unhealthy, $6.6 \%$ said that it was very expensive, $6.1 \%$ said they did not like it, and $12.1 \%$ said that it did not fit their nutritional habits. Among the women $40.5 \%$ and $35.4 \%$ of the men said they found fast food unhealthy. Gender effect on not choosing fast food is significant $\left(\gamma^{2}=28.33 ; \mathrm{P}<0.01\right)$.

\section{Conclusions}

According to our results, among female respondents $6.5 \%$ are overweight and $4 \%$ are obese, while among male respondents $15.2 \%$ overweight and $2.9 \%$ are obese. It is found that the effect of gender on the BMI is significant.

Among the women $37.9 \%$ mentioned that they chose fast food because it was delicious, while $42.2 \%$ of the men said that they chose it because it was prepared quickly. The effect of gender on fast food choice reasons is not significant.

Among the women $38.8 \%$ chose hamburger, $28.5 \%$ chose pizza, while $23.6 \%$ of the men chose hamburger and $22.7 \%$ chose döner. A significant relationship between gender and fast food choice has been found.

Among the $92.6 \%$ women and $87.8 \%$ of the men chose going to fast food restaurants with friends. The effect of gender on the choice with whom to go to fast food restaurant is significant.

Women choose smaller portions in comparison to men. The effect of gender on portion choice is significant. The effect of gender over fast food consumption frequency is significant. 
Among the women $68.4 \%$ and $56.7 \%$ of the men said that hygiene rules are not followed by fast food restaurants. The effect of gender on trust for following hygiene rules in fast food restaurants is significant,

In fast food choice, $60.6 \%$ of the women and $51.5 \%$ of the men said that they are affected by commercials. The relationship between gender and being influenced by commercials is found significant.

Among the women $40.5 \%$ and $35.4 \%$ of the men said that they found fast food unhealthy. Gender effect on not to choose fast food is significant.

Today's college students want to spend little time eating most meals, they tend to like the taste of fast foods, many like to eat with their friends, and many think that fast foods are economical. Eating at fast-food restaurants may be part of their lifestyles.

Nutrition consultants and educators should recognize that college students are going to frequent fast-food restaurants and develop materials useful in helping these young adults consume healthful diets no matter where they eat.

High schools and universities are appropriate establishments for students to gain correct nutritional habits. In these educational establishments it is necessary to offer students sufficient and balanced menus with low charge and it is also necessary to periodically give them nutritional education.

The sale of fast food products, such as hamburger, carbonated soft drinks, and chipsstyle food, in school canteens is forbidden according to the joint decision taken by the Department of Health and the Ministry of Education in 2011-2012 Education and Training. This practice is of great importance for the future generations fighting obesity, encouraging and making students conscious for a healthy diet.

\section{References}

Akbay, C., Tiryaki, G.Y.\& GüL, A. (2007): Consumer characteristics influencing fast food consumption in Turkey. Fd Control, 18, 904-913.

Anon. (2004): FastFoodSurvey-Singapore. http://sg.solutions.yahoo.com/download/ survey/ singapore_fast foodsurvey-june 2004.pdf

Badrie, N., Joseph, A.\&Chen, A. (2004): An observational study of food safety practices by street vendors and microbiological quality of street-purchased hamburger beef patties in Trinidad, West Indies. Internet $J$. Fd Safety, 3, 25-31.

Bender, A.E.\& Bender, D.A. (1995): A dictionary of food and nutrition. Oxford University Press, Oxford, 432 pages.

Davies, G.J. \& Smith, J.L. (2004): Fast food dietary perspective. Nutrition Fd Sci., 34, 80-82.

Demirci, M. (2002): Beslenme (Nutrition). Rebel Publishing, İstanbul.

Demory-Luce, D. (2005): Fast-food and children and adolescents: Implications for practitioners. Clin. Pediatrics, 44, 279-288.

Driskell, J.A., Kim, Y.N.\& Goebel, K.J. (2005): Few differences found in the typical eating and physical activity habits of lower-level and upper-level university students. J. Am. Diet. Assoc., 105, 798-801.

Driskell, J.A., Meckna, B.R.\& Scales, N.E. (2006): Differences exist in the eating habits of university men and women at fast-food restaurants. Nutr. Res., 26, 524-530.

Emerson, R.L. (1990): The new economics of fast food. Van Nostrand Reinhold Publishing, New York, 175 pages.

French, S.A., Harnack, L. \& Jeffery, R.W. (2000): Fast food restaurant use among women in the Pound of Prevention study: dietary, behavioral and demographic correlates. Int. J. Obes., 24, 1353-1359.

French, S.A., Story, M., Neumark-Sztainer, D., Fulkerson, J.A.\& Hannan, P. (2001): Fast food restaurant use among adolescents: associations with nutrient intake, food choices and behavioral and psychosocial variables. Int. J. Obes., 25, 1823-1833.

Garrow, J.S. \& Webster, J. (1985): Quetelet's index (w/h²) as a measure of fatness. Int. J. Obes., 9, 147-153. 
GüLER, B. \& ÖzçElıK, A.Ö. (2002): Çalışan ve Çalışmayan Kadınların Yiyecek Satın Alma-Hazırlama Davranışları Üzerine Bir Araştırma. (Study of food purchasing behaviour of working and unemployed women.) Ankara Üniversitesi Ev Ekonomisi Mezunları Derneği Yayınları Bilim Serisi. 3., Ankara Üniversitesi Basımevi. 91. Ankara

Karabudak, E., Bas, M.\& Kiziltan, G. (2008): Food safety in the home consumption of meat in Turkey. Fd Control, $19,320-327$.

Katzmarzyk, P.T. (2002): The Canadian obesity epidemic, 1985-1998. Can. Med. Assoc. J., 166, 1039-1040.

Lutz, C.\& Przytulski, K. (2001): Nutrition and diet therapy (Third edition). F.A. Davis Company Philadelphia., 668 pages.

Meyers, M.S. \& Wallace, S. (2003): Factors influencing the purchasing of fast food meals. Proc. Acad. Marketing Studies, 8, 51-54.

Morse, K.L.\&Driskell, J.A. (2009): Observed sex differences in fast-food consumption and nutrition selfassessment and belief of college students. Nutr. Res., 29, 173-179.

Nickolas, T.A., Baranowki, T., Cullen, K.W.\& Berenson, G. (2001): Eating patterns, dietary quality and obesity. J. Am. Coll. Nutr., 20, 599-608.

ÖzÇELIK, A.Ö., AKAN, L.S.\& SÜRÜCÜOĞLU, M.S. (2007): An evaluation of fast-food preferences according to gender. Humanity \& Soc. Sci. J., 2, 43-50.

ÖzGEN, L.\&SANLIER, N. (2002): Farkli egitim düzeyindeki ögrencilerin hizli hazir yiyecek (fast food) tüketim durumlarinin saptanmasi. (Determination of fast food consumption of students of different educational levels.) Turizm Akademik, 2, 31-38.

Paeratakul, S., Ferdinand, D.P., Champagne, C.M., Ryan, D.H.\&Bray, G.A. (2003): Fast-food consumption among US adults and children: dietary and nutrient intake profile. J. Am. Diet. Assoc., 103, 1332-1338.

PARK, C. (2004): Efficient or enjoyable? Consumer values of eating-out and fast restaurant consumption in Korea. Int. J. Hospitality Management, 23, 87-94.

SAĞLAM, F. (1991): Hızlı hazır yemek yeme üzerinde bir çalışma. (Study on ready-to-eat fast food.) Beslenme ve Diyet Dergisi, 20, 187-197.

Satia, J.A., Galanko, J.A. \& Siega-Riz, A.M. (2004): Eating at fast food restaurants is associated with dietary intake, demographic, psychosocial and behavioral factors among African-Americans in North Carolina. Public Health Nutr., 7, 1089-1096.

Scheule, B.\& Sneed, J. (2001): From farm to fork: Critical control points for food safety. J. Nutr. Recipe Menu Developm., 3, 3-27.

SHIElds, M. (2006): Overweight and obesity among children and youth. Health Reports, 17, $27-42$.

SIS (2003): Household consumption expenditure survey 2003. State Institute of Statistics, Ankara, Turkey.

Spears, M.C.\& Gregoire, A.C. (2003): Foodservice organizations: a managerial and systems approach, $5^{\text {th }}$ ed., Prentice Hall, Upper Saddle River (NJ), 584 pages.

Statistics CANADa (2006): Canadian community health survey: obesity among children and adults. The Daily, July 6 (2005). Accessed June 8 (2006)

WHO (1984): The role of food safety in health development. Technical Report. Geneva: World Health Organisation, Series 705.

WHO (2004): Surveillance programme for control of foodborne infections and intoxications in Europe. World Health Organisation 8th report, 1999-2000, Country reports: Turkey 